\title{
Proceeding
}

Supplementary Issue: Spring Conferences of Sports Science. International Conference on Psychology of Education Sciences \& Lifestyle.

\section{Comparative study according to the physical patterns in learning some offensive skills basketball for students}

\author{
MOHAMMED SHIHAB AHMED , MOHAMED GHANI, MAYYADAH KHALID JASIM \\ Department of Physical Education and Sport Sciences, Faculty of Basic Education, Mustansiriyah University, \\ Baghdad, Iraq
}

\begin{abstract}
Researchers put the subject to know the relationship between learning and its impact on physical patterns and here lies the importance of research through comparison between the three types of body (skinny - obese - muscular) in learning some offensive skills basketball. The research problem was to ask whether the individual differences in the physical patterns of learners lead to individual differences in the learning of offensive skills in basketball and if there are differences in learning will be in favour of any pattern? The current research aims to: Identify the physical patterns of the students of the first stage and classify them into groups according to those patterns: Identify the differences between groups according to their physical patterns in the results of pre-test tests in some skills in basketball; Identify the differences between groups according to their physical patterns in the results of post-test in some skills in basketball. Therefore, the hypothesis are: There are no statistically significant differences between the results of the pre-test tests for some basketball skills and for the three research groups; There are no statistically significant differences between the results of the post tests for some basketball skills and for the three research groups. The researchers used the descriptive method of comparative study method to suit the nature of the research problem on the students of the first stage in the Department of Physical Education and Sports Science College of Basic Education at the University of Mustansiriyah for the academic year 2014/2015 The number of female students (28) has been identified three types of body (fat - muscular - The formula for calculating the physical pattern and classifying them according to pre-established criteria has been adopted. Based on the experience of the researchers, the skills under study were identified (high medical, low medical, free throw, peaceful correction) and after conducting pre-test tests and implementing the termination. Educational and then posteriori tests were statistical processors reached through which the researchers to: There were no significant differences between the groups according to the physical patterns in the performance of some motor skills in basketball for pre-tests. There were no significant differences between groups according to the physical patterns in the performance of some motor skills in basketball for post - tests.
\end{abstract}

Keywords: Physical patterns; Offensive; Basketball.

Cite this article as:

Ahmed, M.S., Ghani, M., \& Jasim, M.K. (2020). Comparative study according to the physical patterns in learning some offensive skills basketball for students. Journal of Human Sport and Exercise, 15(3proc), S938-S943. doi:https://doi.org/10.14198/ihse.2020.15.Proc3.45

Corresponding author. Department of Physical Education and Sport Sciences, Faculty of Basic Education, Mustansiriyah University, Baghdad, Iraq. https://orcid.org/0000-0001-9725-5680

E-mail: zahraa_ammer@yahoo.com

Supplementary Issue: Spring Conferences of Sports Science. International Conference on Psychology of Education Sciences and Lifestyle.

JOURNAL OF HUMAN SPORT \& EXERCISE ISSN 1988-5202

(c) Faculty of Education. University of Alicante

doi:10.14198/jhse.2020.15.Proc3.45 


\section{INTRODUCTION}

Basketball has many basic and varied skills and often takes time to reach the desired results with much effort required. He defines learning as a permanent change in motor behaviour as a result of repetition and correction (Oslin et al., 1998). They are (slim, chubby, and muscular).

Despite the many modern methods of learning the motor skills of all sports, including the game of basketball and as noted through the large number of applied research that dealt with learning methods and after researchers note the large number of research and studies on learning methods and note the impact of individual differences of the learner and controlled some of the physical patterns in Learning. Learning influenced the learner's physical patterns and ability to skill performance (Chow et I., 2007).

Hence, researchers found that there are individual differences to learn the motor skills of basketball, which are governed by physical patterns and affect the interaction with learning performance, but any patterns interact more and here manifests the problem of research to start researchers to find the most appropriate solutions and identify the best patterns in a scientific way sober and objective far from prejudice and prediction (Turner \& Martinek, 1995).

\section{RESEARCH METHODOLOGY}

The researchers used the descriptive method of comparative study to suit its relevance and the nature of the research problem.

\section{Community and research sample}

Have been identified research community of students in the first stage in the Department of Physical Education and Sports Science Faculty of Basic Education at Mustansiriya University for the academic year 2017/2018. The number of female students reached 28 female students out of (32) as the percentage of the sample (87.5\%) were selected the sample was deliberate, and (4) female athletes were excluded for lack of discipline.

\section{Field procedures}

Determine the physical pattern

After reviewing the previous books, researches and studies, the researchers reached the consensus of most specialists to identify three types of physical (fat - muscular - slim).

Patterns $=[($ upper arm $\times 0.808)+($ forearm $\times 0.601)+($ total weight $\times 0.188)+($ leg length $\times 0.161)-($ hip length $x$ 0.131)] (Papastergiou, 2009).

\section{Identification Skills}

Based on the experience of the researchers, the skills under study were identified. The skills are:

1. High dribble.

2. Low dribble.

3. Free throw.

4. Layup shooting.

Tests used in the research

1. High dribble test. 
2. Low dribble test.

3. Free throw test.

4. Layup shooting test (Pereira et al., 2015).

\section{Pre-test}

The researchers conducted the skills test (High dribble, Low dribble, Free throw, and Layup shooting) on Sunday, 15/3/2018 in the closed sports hall at the College of Basic Education/ University of Mustansiriyah at $8: 30 \mathrm{am}$ and the researchers tested the skills mentioned.

\section{Educational program}

The educational modules used for the four skills under consideration were numbered (7) teaching units and by an educational unit during the week and a time of 90 minutes per unit of education has been explained and introduced and applied skills in accordance with the scientific foundations used in learning the skills of basketball game and by a specialist material teacher (Brooker et al., 2000).

\section{Post-test}

The tests were conducted after (7) weeks of the pre-test of the skills under discussion on Sunday 24/4/2018 and in the same place and time of the pre-test.

\section{Statistical means}

For the purpose of statistical processing, the researchers used statistical methods by means of SPSS.

\section{RESULTS}

Table 1. Statistical description of skills by group for pre-test tests.

\begin{tabular}{llllllll}
\hline Skills & Groups & N & Mean & SD & Standard error & Max & Min \\
\hline \multirow{3}{*}{ High dribble } & Thin & 8 & 13.25 & 1.83 & 0.64 & 16.00 & 11.00 \\
& muscular & 10 & 13.80 & 2.48 & 0.78 & 17.00 & 10.00 \\
& Obese & 10 & 12.50 & 1.08 & 0.34 & 15.00 & 11.00 \\
\hline \multirow{3}{*}{ Low dribble } & Thin & 8 & 14.37 & 1.06 & 0.37 & 16.00 & 13.00 \\
& muscular & 10 & 14.50 & 1.64 & 0.52 & 16.00 & 11.00 \\
& Obese & 10 & 13.60 & 1.95 & 0.61 & 16.00 & 11.00 \\
\hline \multirow{3}{*}{ Free throw } & Thin & 8 & 12.25 & 1.28 & 0.45 & 14.00 & 11.00 \\
& muscular & 10 & 13.80 & 1.61 & 0.51 & 17.00 & 11.00 \\
& Obese & 10 & 13.10 & 2.13 & 0.67 & 17.00 & 12.00 \\
\hline \multirow{3}{*}{ Layup shooting } & Thin & 8 & 11.00 & 1.77 & 0.62 & 15.00 & 9.00 \\
& muscular & 10 & 12.40 & 2.06 & 0.65 & 16.00 & 9.00 \\
& Obese & 10 & 11.00 & 1.63 & 0.51 & 14.00 & 9.00 \\
\hline
\end{tabular}

Table 2. Shows the value of (f) and the significance level of the differences between the totals for the pretest tests.

\begin{tabular}{|c|c|c|c|c|c|c|c|}
\hline Skills & Groups & $\begin{array}{l}\text { Sum of } \\
\text { squares }\end{array}$ & $\begin{array}{l}\text { Average } \\
\text { squares }\end{array}$ & df & $\begin{array}{l}\text { Calculated } \\
\text { (f) value }\end{array}$ & $\begin{array}{l}\text { Significance } \\
\text { level }\end{array}$ & $\begin{array}{l}\text { Type of } \\
\text { significance }\end{array}$ \\
\hline \multirow{2}{*}{$\begin{array}{l}\text { High } \\
\text { dribble }\end{array}$} & $\begin{array}{l}\text { Between } \\
\text { groups }\end{array}$ & 8.50 & 4.254 & 2 & \multirow{2}{*}{1.187} & \multirow{2}{*}{.322} & \multirow{2}{*}{ Non sig. } \\
\hline & $\begin{array}{l}\text { Within } \\
\text { groups }\end{array}$ & 89.60 & 3.584 & 25 & & & \\
\hline
\end{tabular}




\begin{tabular}{llllllll}
\hline $\begin{array}{l}\text { Low } \\
\text { dribble }\end{array}$ & $\begin{array}{l}\text { Between } \\
\text { groups }\end{array}$ & 4.65 & 2.327 & 2 & & & \\
& $\begin{array}{l}\text { Within } \\
\text { groups }\end{array}$ & 66.77 & 2.671 & 25 & 0.871 & .431 & Non sig. \\
\hline $\begin{array}{l}\text { Free } \\
\text { throw }\end{array}$ & $\begin{array}{l}\text { Between } \\
\text { groups }\end{array}$ & 10.67 & 5.339 & 2 & & & \\
& $\begin{array}{l}\text { Within } \\
\text { groups }\end{array}$ & 76.00 & 3.040 & 25 & 1.756 & .193 & Non sig. \\
\hline $\begin{array}{l}\text { Layup } \\
\text { shooting }\end{array}$ & $\begin{array}{l}\text { Between } \\
\text { groups } \\
\text { Within } \\
\text { groups }\end{array}$ & 12.60 & 6.300 & 2 & & & \\
\hline
\end{tabular}

Table 3. Shows the value of $f$ and the significance level of the differences between the totals for the post tests.

\begin{tabular}{|c|c|c|c|c|c|c|c|}
\hline Skills & Groups & $\begin{array}{l}\text { Sum of } \\
\text { squares }\end{array}$ & $\begin{array}{l}\text { Average } \\
\text { squares }\end{array}$ & df & $\begin{array}{l}\text { Calculated } \\
\text { (f) value }\end{array}$ & $\begin{array}{l}\text { Significance } \\
\text { level }\end{array}$ & $\begin{array}{l}\text { Type of } \\
\text { significance }\end{array}$ \\
\hline \multirow{2}{*}{$\begin{array}{l}\text { High } \\
\text { dribble }\end{array}$} & $\begin{array}{l}\text { Between } \\
\text { groups }\end{array}$ & 8.33 & 4.170 & 2 & \multirow{2}{*}{0.896} & \multirow{2}{*}{.421} & \multirow{2}{*}{ Non sig. } \\
\hline & $\begin{array}{l}\text { Within } \\
\text { groups }\end{array}$ & 116.37 & 4.655 & 25 & & & \\
\hline \multirow{2}{*}{$\begin{array}{l}\text { Low } \\
\text { dribble }\end{array}$} & $\begin{array}{l}\text { Between } \\
\text { groups }\end{array}$ & 2.60 & 1.302 & 2 & \multirow{2}{*}{0.542} & \multirow{2}{*}{.588} & \multirow{2}{*}{ Non sig. } \\
\hline & $\begin{array}{l}\text { Within } \\
\text { groups }\end{array}$ & 60.07 & 2.403 & 25 & & & \\
\hline \multirow{2}{*}{$\begin{array}{l}\text { Free } \\
\text { throw }\end{array}$} & $\begin{array}{l}\text { Between } \\
\text { groups }\end{array}$ & 14.57 & 7.289 & 2 & \multirow{2}{*}{3.137} & \multirow{2}{*}{.061} & \multirow{2}{*}{ Non sig. } \\
\hline & $\begin{array}{l}\text { Within } \\
\text { groups }\end{array}$ & 58.10 & 2.324 & 25 & & & \\
\hline \multirow{2}{*}{$\begin{array}{l}\text { Layup } \\
\text { shooting }\end{array}$} & $\begin{array}{l}\text { Between } \\
\text { groups }\end{array}$ & 13.02 & 6.514 & 2 & \multirow{2}{*}{3.365} & \multirow{2}{*}{.051} & \multirow{2}{*}{ Non sig. } \\
\hline & $\begin{array}{l}\text { Within } \\
\text { groups }\end{array}$ & 48.40 & 1.936 & 25 & & & \\
\hline
\end{tabular}

\section{DISCUSSION OF THE RESULTS}

After reviewing Tables 2 and 3 it is clear to us that the learning process was going to serve the main objective of the material, and we note that there are no differences between the groups under study in learning these skills according to their physical patterns.

Researchers attribute this to the fact that the learning process of the skills under study did not have a significant factor in the pattern of physical differences in the differences between these groups, and may occur differences in other skills, researchers attribute this view that the learning process was subject to sufficient time and adequate repetition, which melts the impact of the physical pattern in Learn these skills (Chen \& Ennis, 1996). 
This statement also reinforces statement that "physical patterns have a clear and significant role in physical abilities," meaning that the motor abilities associated with learning did not record significant differences (Nasir \& Hand, 2008). If we go beyond that in determining and analysing the reasons that led to the emergence of moral differences between the members of the research groups we see and through the link to three main axes closely related to the subject of research, namely (skill, learning and physical patterns) If we researched the acquisition of skill and learning to find that all The process of learning and any skill was due to the occurrence of internal changes in the individual and these changes are within the central nervous system and the formation of motor programs "which is defined as a set of preconceptions of motor orders (alphakama) (Alsayigh et al., 2017), which results in movements directed to specific targets It is a result of its effects and is not affected by the peripheral feedback or return of information even if the feedback and information returns aim to change the target and stored in memory and this characteristic (the formation of motor programs) and that these programs are characterized by individuals of different physical patterns as the central nervous system is available and works efficiently close to Most of the individuals are normal and here we note that learning is closely related to the efficiency of the work of the central nervous system and through this relationship we can explain the lack of correlation of the acquisition of research skills nature of the physical pattern of the sample individuals Physical patterns have an impact on physical abilities, this talk makes sense, but the proportion of the contribution of physical abilities to learn skills a small percentage as the learner does not need in the beginning of learning a large amount of force and speed, for example, that the learner needs to be more precise in that stage than the need for speed and power, for example (Alsayigh \& Athab, 2016).

It is worth mentioning that all research groups have an event to learn the skills researched and researchers attribute the reason for this repetition and organized practice being the only way to create nerve connections within the learner's brain (Jumaah et al., 2008), which represents the acquisition of experience and this is confirmed by expressing quoted (Sage) by saying that "learning is Internal change occurs in the nerves as a result of accumulation of experience " (Athab et al., 2019).

This is what we mean by learning that is an internal change in addition to that the inference to learning is through behaviour and this behaviour is related to the work of the central nervous system and efficiency more than linked to physical patterns and this is consistent with what he said," It is not a permanent change in motor behaviour as a result of repetition and correction, and that this change cannot be rectified directly, but indirectly through behaviour" (Athab, 2019).

\section{CONCLUSIONS}

There were no significant differences between groups according to the physical patterns in the performance of some motor skills in basketball for pre-tests.

There were no significant differences between groups according to the physical patterns in the performance of some motor skills in basketball for post-tests.

\section{REFERENCES}

Alsayigh, H. A., \& Athab, N. A. (2016). The Study of Rectus Femoris Activity after Knee Joint Rehabilitation. International Journal of Pharm Tech Research, 9(9), 360-365. 
Alsayigh, H. A., Athab, N. A., \& Firas, M. (2017). The Study of Electrical Activity of the Triceps Brachia Muscle according to the Chemical Changes of Water Loss during Spike in Volleyball. Journal of Global Pharma Technology, 57-62.

Athab, N. A. (2019). An Analytical Study of Cervical Spine Pain According to the Mechanical Indicators of the Administrative Work Staff. Indian Journal of Public Health Research \& Development, 10(5), 1348-1354. https://doi.org/10.5958/0976-5506.2019.01184.7

Athab, N. A., Hussein, W. R., \& Ali, A. A. M. (2019). A Comparative Study for Movement of Sword Fencing Stabbed According to the Technical Programming in the Game of Fencing Wheelchairs Class B. Indian Journal of Public Health Research \& Development, 10(5), 1344-1347. https://doi.org/10.5958/0976-5506.2019.01183.5

Brooker, R., Kirk, D., Braiuka, S., \& Bransgrove, A. (2000). Implementing a game sense approach to teaching junior high school basketball in a naturalistic setting. European Physical Education Review, 6(1), 7-26. https://doi.org/10.1177/1356336X000061003

Chen, A., \& Ennis, C. D. (1996). Teaching value laden curricula in physical education. Journal of teaching in physical education, 15(3), 338-354. https://doi.org/10.1123/itpe.15.3.338

Chow, J. Y., Davids, K., Button, C., Shuttleworth, R., Renshaw, I., \& Araújo, D. (2007). The role of nonlinear pedagogy in physical education. Review of Educational Research, 77(3), 251-278. https://doi.org/10.3102/003465430305615

Jumaah, H., Ktaiman, A., Abdul, N., Athab, K., \& Mohammed, A. (2008). The Effect of Using Pain Management Techniques in the Rehabilitation of Chronic Lower Back Injury in Athletes and NonAthletes. Journal of Global Pharma Technology, 10(7), 78-82.

Papastergiou, M. (2009). Exploring the potential of computer and video games for health and physical education: A literature review. Computers \& Education, 53(3), 603-622. https://doi.org/10.1016/i.compedu.2009.04.001

Pereira, J., Hastie, P., Araújo, R., Farias, C., Rolim, R., \& Mesquita, I. (2015). A comparative study of students' track and field technical performance in sport education and in a direct instruction approach. Journal of sports science \& medicine, 14(1), 118.

Oslin, J. L., Mitchell, S. A., \& Griffin, L. L. (1998). The game performance assessment instrument (GPAl): Development and preliminary validation. Journal of teaching in physical education, 17(2), 231-243. https://doi.org/10.1123/itpe.17.2.231

Nasir, N. I. S., \& Hand, V. (2008). From the court to the classroom: Opportunities for engagement, learning, and identity in basketball and classroom mathematics. The Journal of the Learning Sciences, 17(2), 143-179. https://doi.org/10.1080/10508400801986108

Turner, A., \& Martinek, T. J. (1995). Teaching for understanding: A model for improving decision making during game play. Quest, 47(1), 44-63. https://doi.org/10.1080/00336297.1995.10484144

\section{() $\odot \Theta \Theta$}

This work is licensed under a Attribution-NonCommercial-NoDerivatives 4.0 International (CC BY-NC-ND 4.0). 